\title{
The Situation of the Hungarian Wheat from the Grain Trading Point of View in 2016
}

\author{
Ph.D. Candidate András Bence Szerb (Kaposvár University, Hungary) \\ Dr. Ferenc Csima (Kaposvár University, Hungary)
}

\begin{abstract}
Hungary is traditionally an agricultural country and the agricultural sector is still a dominant one in the economy but its importance is weakening nowadays. The agriculture is export oriented, which helps to improve the performance of the national foreign trade balance of the country.

On a global scale wheat is one of the most important grain products both globally and in Hungary as well. During the past years wheat has had the second biggest volume after corn on the local market. In this paper the authors examine the situation of the wheat according to data bases of different institutions both on the Hungarian and the international markets.

On the global agricultural market, the grain sector plays a decisive role since it produces the necessary basic food for humanity. During the last decades the sector has needed to face higher demands for grain products on the agricultural markets which trend may probably continue in the near future as well. The volume increase of the products has affected the agribusiness markets also. Such a small and export oriented country like Hungary should follow the global and EU trends on the agricultural market to keep its competitiveness.
\end{abstract}

\section{Introduction}

For long centuries Hungary was traditionally a country where the dominance of agriculture within the national economy was significant. Agriculture was important because of employment, food supply but at the same time it played an important role in the daily life of the families (Nagy, 2006). The Hungarian agriculture has gone through important and fast changes during the last decades of the previous century. First the Soviet system collapsed which caused a big shock for the agriculture, which the transition period of the 90s followed and in 2004 Hungary joined the EU where the country had to integrate into a new system again. The changes affected not just the agriculture itself but the trading directions of the products as well in the whole Central-East European Region (Fertö, 2006). $13.7 \%$ of the GDP was produced by the agriculture in 1989 and $17 \%$ of the employed people worked in the sector. By the millennium the agricultural sector lost its weight in the national economy (Kiss, 2002). 4.1\% of the GDP was produced in 2001 by the agriculture in Hungary while in 2004 this number decreased even more until 3.7\% and only $4.6 \%$ was the share of the sector from the employment.

Even though the previously mentioned negative changes characterized the sector during the past decades the Hungarian agriculture is still a dominant part of the economy. Out of the total territory of the country $79 \%$ is cultivation land and 5.3 million hectare is used by the sector. The export import ratio of agriculture has been positive during the past years. From the study's point of view it is more important that during the last three years the volume of wheat has been over 5 million tons/year in Hungary. The sown area of wheat is quite stable in the country and it is the second most important crop after corn. The agriculture of Hungary is important not just on the national level but also in the EU. $2 \%$ of the total output of the EU has been produced by the country, but the performance has been even more dominant in case of crops $(2.3 \%)$ and in the grain sector where Hungary's production has reached almost the 5\% in 2014 (KSH, 2015).

\section{Wheat on the Global Market}

The world wheat production shows increasing tendency according to the data of Table 1 and with its volume wheat is among the most popular crops of the world besides the leader corn and rice. In the last crop year more than 14 million tons of wheat was harvested than 2 years before in 2013/14. The biggest change which is visible in the table is the volume increase of the EU. In the last two years the volume has increased by 15 million tons. Besides the volume increase of the EU Russia and Ukraine which are geographically close and have influence on the EU market could have increase their volume as well in the past years. There is a slight volume decrease visible in case of the USA while more dramatic decrease can be examined in Canada and India. In Asia, China could increase its productions in the past years. 


\begin{tabular}{|c|c|c|c|}
\hline Country & $13 / 14$ & $14 / 15$ & $15 / 16$ \\
\hline EU & 143 & 156 & 158 \\
\hline Russia & 52 & 59 & 61 \\
\hline USA & 58 & 55 & 56 \\
\hline Ukraine & 22 & 25 & 27 \\
\hline Canada & 38 & 29 & 28 \\
\hline Australia & 25 & 23 & 24 \\
\hline Kazahstan & 14 & 13 & 14 \\
\hline Argentina & 9 & 14 & 11 \\
\hline China & 122 & 126 & 130 \\
\hline India & 94 & 96 & 87 \\
\hline World total & 717 & 728 & 731 \\
\hline
\end{tabular}

Table 1. Wheat Production of the World (million tons) Source: MGTKSZ (2016a)

On the world market according to FAPRI (2011) projections the net trade of wheat grows $2.5 \%$ on an annual base and it may reach $135 \mathrm{mmt}$ in 2025/26. There might be changes in terms of the market share of exporters and importers as well according to the projections. The net wheat import of the African countries may increase with $13.5 \mathrm{mmt}$ while Asians with $1.2 \mathrm{mmt}$ over the next fifteen years. The market share of the USA on the world export market of wheat declines while the position of China and India might be stronger in 2025/26.

According to the projections of OECD (2014) the prices of the major cereals, including wheat remain under downward pressure in the near future. As the forecasts shows the price of wheat has mostly followed the price trends of the other cereals during the past years. The projection of OECD (2014) says that the prices of corn, rice and wheat may slightly decrease until 2023 compared to the beginning of the decade. The oilseed products have different future in term of prices according to the projection as there is a slightly increasing price visible in the trends. The price differences may be constant, which means that wheat will probably stay in the third position just in front of corn as it is visible in Table 2.

\begin{tabular}{|l|r|r|r|r|r|}
\hline & \multicolumn{7}{|c|}{ EU-27/EU-28 (Croatia from 01.07.2013.) } \\
\hline & \multicolumn{7}{|c|}{$\mathbf{2 0 1 6}$} & \multicolumn{7}{|c|}{$\mathbf{2 0 1 5}$} & $\mathbf{2 0 1 4}$ & $\mathbf{2 0 1 3}$ & $\mathbf{2 0 1 2}$ \\
\hline Wheat & 24164 & 24238 & 24155 & 23223 & 22801 \\
\hline Land & 60 & 62 & 61 & 59 & 56 \\
\hline Yield & 145225 & 150328 & 148504 & 136453 & 127008 \\
\hline Crop & 57129 & 56634 & 57313 & 57225 & 55992 \\
\hline Grains Total & 54 & 55 & 57 & 53 & 50 \\
\hline Land & 306282 & 308864 & 325046 & 301097 & 281751 \\
\hline Yield & \multicolumn{7}{|c|}{}
\end{tabular}

Table 2. EU Volume Production between 2012-2016 (land $1.000 \mathrm{ha} /$ yield $100 \mathrm{~kg} / \mathrm{ha} / \mathrm{crop} 1.000$ t) Source: COCERAL, 2016.

Getting closer towards the Hungarian market the paper must show some data about the wheat market of the European Union. As the data of Table 2 shows the arable land use of wheat has increased during the past years just as it is visible in case of grains in total. In case of yield in both cases in the shown period the numbers reflect that the changes are not significant and it rather happened because of the weather conditions of the given year of the continent than the changes in the sector. The situation of crop is in parallel to land and yield so the same tendency is visible in the table.

According to MGTKSZ (2016b) the wheat balance of the EU in 2016/17 crop year might be more balanced than in the past years. After a relatively high open stock (17million tons), a lower volume of harvested crop and also import is expected. The processing industry is significant and stable and in the meantime the export import balance of the EU has been positive in the past years as it has exported more than imported. The question of the near future is the issues of the position and the situation of the Ukrainian and the Russian markets because they produce a huge volume of wheat and traditionally at a lower price than the production of the EU states. The stronger integration of the Ukraine within the EU might have effect on mostly the Central-Eastern European agricultural market.

\section{Hungarian Wheat's Position on the Domestic and Foreign Markets}

Hungary is a small country with a relatively big cultivation area. There is more than 7.3 million hectares of land available in Hungary and out of this the use of agriculture is around 5.3 million hectares which means it is more than the $80 \%$ of its arable land. The grain production is one of the most dominant within the agricultural sector. In $2015,38 \%$ of the total harvested area of grains was wheat which followed long years of tradition as wheat was the second most dominant crop after corn and before barley (KSH, 2016). In case of average volume 2015 was a good 
crop year in Hungary for wheat as it was higher than 5 tons/hectare. The total volume of wheat has been over 5 million tons during the past three years in Hungary which represents stability at wheat production on the market as Figure 2 shows.

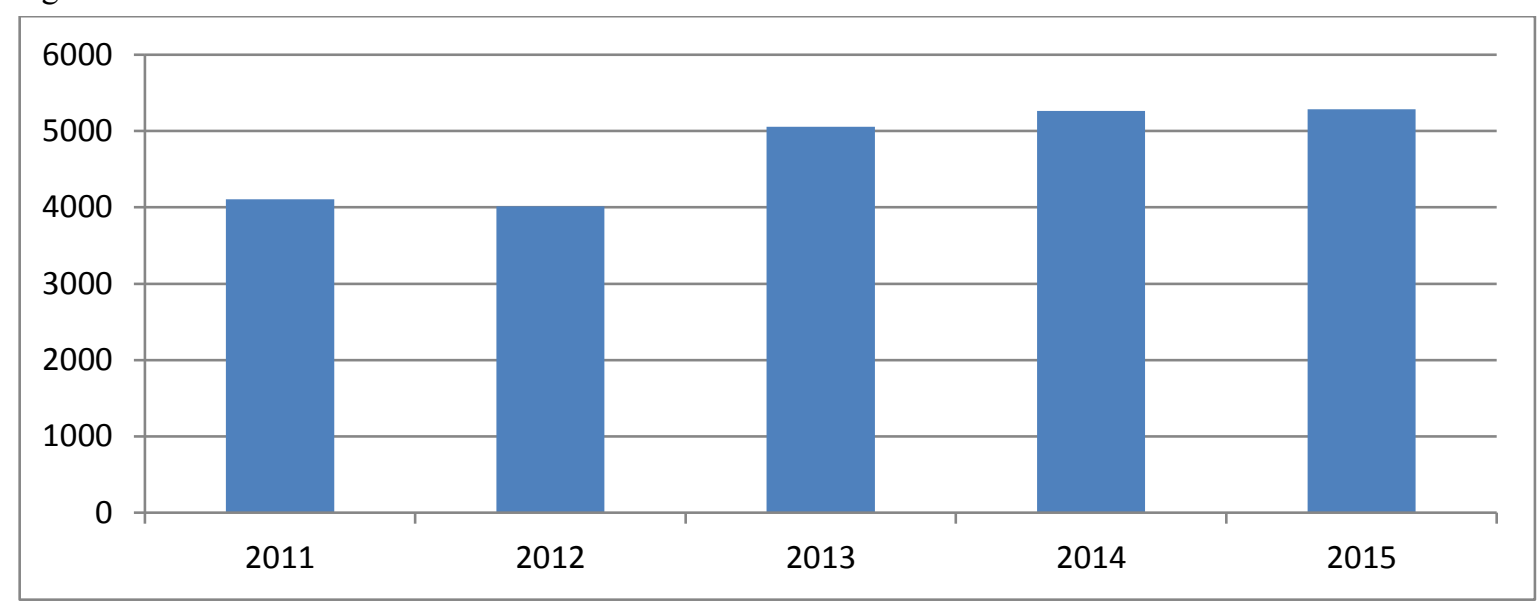

Figure 1. Harvested Volume of Wheat in Tons in Hungary Source: The Author's Own Construction Based on KSH (2016)

The volume of wheat produced in the country is significant domestically compared to other crops, but on the EU level the average production of Hungary was between $3 \%$ and $4 \%$ of the total production as Table 3 shows. The market leaders (Germany, Great Britain, Poland, France) are taking a huge share of the EU market but regionally the situation is better. In the Central-East European Region Hungary is between the biggest producers with Romania and Bulgaria.

\begin{tabular}{|c|c|c|c|c|c|}
\hline & 2005 & 2006 & 2007 & 2008 & 2009 \\
\hline Hungary & 5088 & 4376 & 3987 & 5631 & 4419 \\
\hline EU 28 & 136030 & 127540 & 121076 & 151200 & 139480 \\
\hline & 2010 & 2011 & 2012 & 2013 & 2014 \\
\hline Hungary & 3745 & 4107 & 4011 & 5058 & 5262 \\
\hline EU 28 & 137574 & 138744 & 136488 & 144280 & 157230 \\
\hline
\end{tabular}

Table 3. Volume of Wheat between 2005-2014 in Hungary Source: KSH (2016)

The data of Figure 2 shows that the export volume of wheat in the past three years has increased compared with the 1.5 million tons of annual export during the first years of the decade. In the meantime the authors must highlight that there is a slightly decreasing tendency visible in Figure 2 between 2013 and 2015.

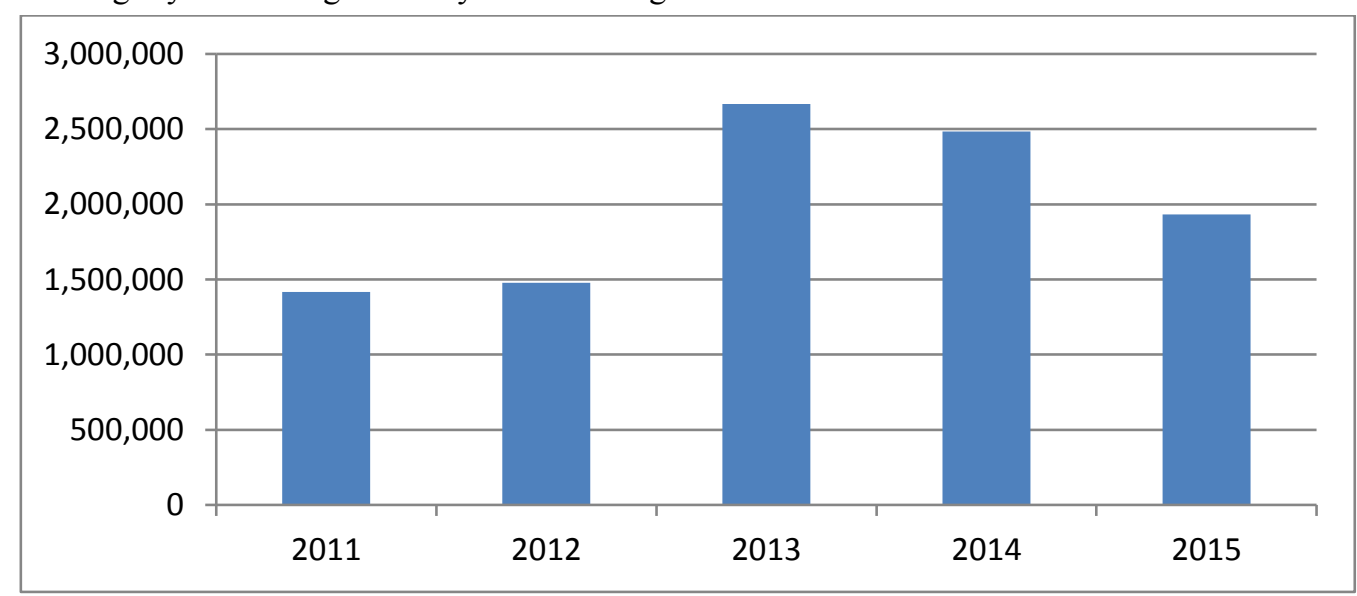

Figure 2. Hungarian Wheat Export in Tons between 2011-2015 Source: The Author's Own Construction Based on MGTKSZ, $2016 \mathrm{~b}$

The Hungarian wheat export is quite concentrated as Figure 3 shows. After the country joined the EU in 2004 the main export direction of the product went towards different EU member states and this tendency is similar also today. Almost $90 \%$ of the total exported volume went to the EU in 2015 . Traditionally Italy is the most dominant export direction of Hungarian wheat because of its huge processing sector and in 2015 more than $35 \%$ of the total wheat export of the country was exported there. Other dominant countries where the Hungarian export has gone are traditionally our neighbors like Romania, Austria and also Slovenia which has a big processing sector compared to the size of the country. In case of the 3rd country only $10 \%$ of the export volume was exported there but an 
important fact that $91 \%$ of this volume went to Bosnia and Hercegovina. The country at the West Balkan has become a significant export market during the past years.

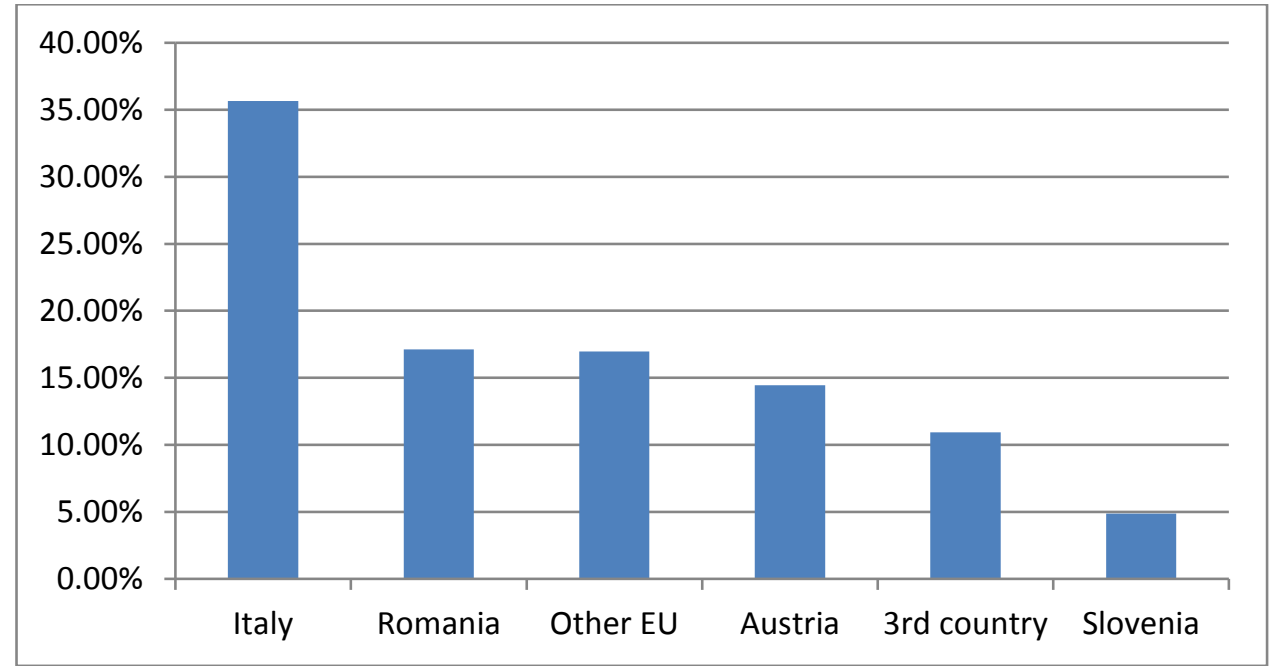

Figure 3. Hungarian Wheat Export by Countries in 2015 (KN:10019099) Source: The Author's Own Construction Based on MGTKSZ, $2016 c$.

In case of freight types as it is visible in Figure 4 there have been changes in the past years. Although truck is still the most dominant freight type but both river transport and train transport could increase their volume. In case of train export there was a slight increase from 2010 which basically followed the export volume increase of the product itself. The biggest change is visible if we look at the export data of the volume done on the Danube. The exported wheat done on the river was quadrupled in the examined period of Figure 4. The authors expect some changes in case of the main export direction because of the increased export volume of wheat along the Danube during the last years. Probably the export volume shifts towards countries along the Danube in the next years. Besides all the previously mentioned facts in case of the Danube export the exporter should take into consideration the risks originated from the nature (low water level, flooding).

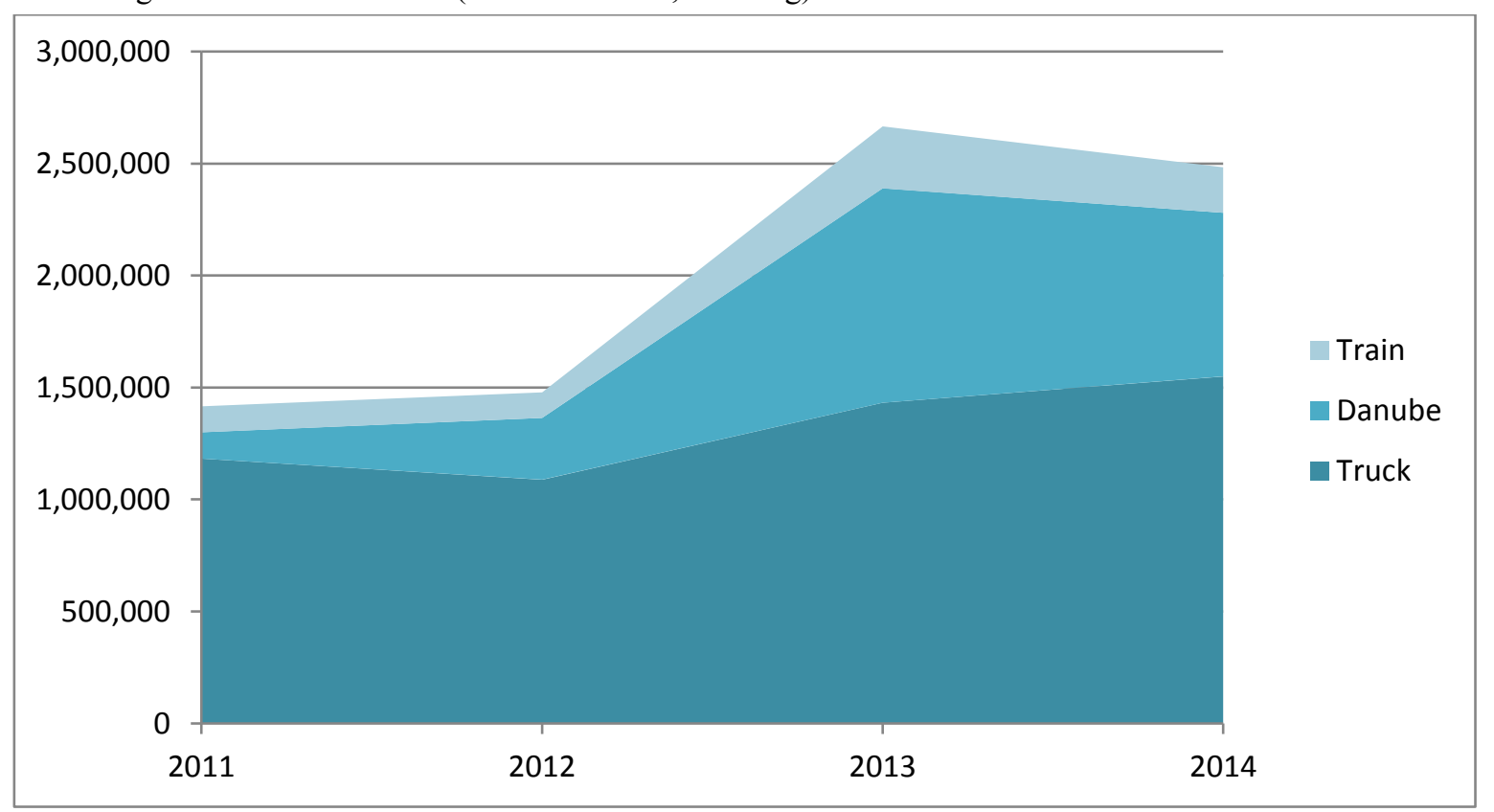

Figure 4. Wheat Export by Freight Types between 2011-2014 in Hungary. Source: The Authors' Own Construction Based on MGTKSZ, $2016 c$.

\section{Conclusions}

Hungary is a country where agriculture has long centuries of history. Today as the country is part of the global agricultural market it must follow the global trends of the sector. The position of the wheat on the world market of different crops is relatively stable. During the past decades wheat has been one of the world's most dominant cereal besides corn and rice and according to different forecasts this tendency may go on. In Hungary this tendency is 
similar. Wheat is the second most important product after corn on the domestic market and its position is stable with its sowing area and its increasing volume year by year. Besides the domestic market the wheat export of Hungary is also significant mainly on the agribusiness market of the Central-East European region as the main importers of the product are the countries situated close to the Hungarian border.

There are questions in the near future with regard to Hungarian wheat such as the domestic sowing structure and the issues of neighboring countries as there are some changes visible. Oil seeds are taking bigger areas year by year while there is a slight decrease in case of corn sowing area in Hungary. A bigger issue is the question and the position of the Ukraine as it has huge available arable land and data shows increasing volume of wheat in the past years. The future integration of the Ukraine to the EU might cause significant changes mainly in the Central European market including Hungary. Another open question is the Russian embargo. Russia has a huge agricultural market and production and the country is situated close to Hungary so all dramatic changes in its agribusiness sector probably has an effect on the domestic wheat production of Hungary as well.

\section{References}

- FAPRI, 2011. Overview of the FAPRI-ISU 2011 World Agricultural Outlook, http://www.fapri.iastate.edu/outlook/2011/text/commodity_overview.pdf

- Fertő, 2006. Az agrárkereskedelem átalakulása Magyarországon és a Kelet- Közép Európai országokban. MTA Közgazdaságtudományi Intézet, Budapest

- Kiss, 2002. A magyar mezőgazdaság világgazdasági mozgástere. Akadémiai Kiadó Rt., Budapest

- Nagy G. (2006): Country Pasture/Forage Resource Profiles - Hungary. FAO, Rome

- $\quad$ COCERAL, 2016. EU-28 GRAIN CROP FORECAST March 2016., http://www.coceral.com/data/1457967495Corrigendum\%20\%20Coceral\%20GRAIN\%20estimates_2016_March_11032016.pdf

- MGTKSZ, 2016a. Kereskedelmi hírlevél 0316, http://www.gabonaszovetseg.hu/hirek.php?c=4028

- MGTKSZ, 2016b. Kereskedelmi hírlevél 0516, http://www.gabonaszovetseg.hu/hirek.php?c=4042

- $\quad$ MGTKSZ, 2016c. Export-import, downloaded (2016.03.30.) http://www.gabonaszovetseg.hu/informaciobazis.php? $\mathrm{m}=$ exportimport

- $\quad \mathrm{KSH}, 2015$. A mezőgazdaság szerepe a nemzetgazdaságban, 2014, http://www.ksh.hu/docs/hun/xftp/idoszaki/mezo/mezoszerepe14.pdf

- KSH, 2016. Táblák (STADAT) - Idősoros éves adatok - Mezőgazdaság, https://www.ksh.hu/stadat_eves_4_1

- OECD/Food and Agriculture Organization of the United Nations, 2014. OECD-FAO Agricultural Outlook 2014, https://www.embrapa.br/documents/10180/9523522/OECD-FAO+Agricultural+Outlook+20142023/3d92f64c-5d31-48e5-bce5-779ae6d88018 